\title{
Omega 3 fatty acids in the elderly
}

\author{
Natalia Úbeda, María Achón and Gregorio Varela-Moreiras* \\ Departamento de Ciencias Farmacéuticas y de la Alimentación, Facultad de Farmacia, Universidad CEU San Pablo, Urb. \\ Monteprincipe, Ctra. Boadilla km. 5,3, 28668, Boadilla del Monte (Madrid), Spain
}

\begin{abstract}
Population ageing affects the entire world population. Also at world level one can observe a sharp increase in the proportion of older people. The challenge posed by population ageing translates into ensuring that the extra years of life will be as good as possible, free from high-cost dependency. Omega-3 fatty acids are now generally recognized as potential key nutrients to prevent the pathological conditions associated to the aging process. Ageing physiological process, its association with quality of life and the impact of omega- 3 fatty acids intake and/or status is the focus of the present review. This report deals with the effects of omega- 3 fatty acids on normal aging of older adults $(\geq 65$ years) mainly on the effects such as nutritional status itself, cognition, bone health, muscle tonus, and general health status. The preliminary broad search of the literature on the effects of omega- 3 fatty acids on normal aging yielded 685 citations. Forty two full text papers were checked for inclusion and thirty six studies were finally included in this review. It may be concluded that paradoxically even though the elderly population is the largest one, the number of studies and the methodology employed clearly lacks of sufficient evidence to establish definite conclusions on the effects of omega-3 fatty acids on aging metabolism without pathological conditions and on quality of life.
\end{abstract}

Key words: Bone diseases: Bone fractures: Omega-3 fatty acids: Osteoblast: Osteoclast: Osteoporosis: Systematic review

\section{Introduction}

Over a period of 100 years, the proportion of people aged 60 and more will triple, from a mere $11 \%$ in 1950 to no less than $33 \%$ in $2050^{(1-4)}$. Nutrition is one of the major determinants of successful aging, defined as the ability to maintain three key elements: low risk of disease and disease-related disability, high mental and physical function, and active engagement of life ${ }^{(5-6)}$. Food is not only critical to one's physiological well-being but also contributes to one's social, cultural, and psychological quality of life ${ }^{(7)}$. In fact, quality of life is mentioned worldwide as an important issue in future research related to active and healthy "successful" ageing.

Physiological and functional changes that occur with aging can result in changes in nutrient needs ${ }^{(8-9)}$. Knowledge of nutrient requirements of older adults is growing yet is still inadequately documented ${ }^{(10-11)}$. Older adults have unique nutrient needs ${ }^{(12)}$. Both cross-sectional and longitudinal studies document that the quantity of food and energy intake usually decreases substantially across the spectrum of aging. Surprisingly, there is a lack of information about fatty acids, mainly long-chain polyunsaturated omega-3. Strategies to prevent and (or) reduce morbidity in the elderly are therefore required as worldwide the population ages. Increasing the intake of omega- 3 , particularly the long-chain $n-3$ PUFA may be one such strategy ${ }^{(13-15)}$.

Omega-3 fatty acids are now generally recognized as potentially beneficial for optimal function of the cardiovascular system in adults ${ }^{(16-17)}$. As clear examples, because of the increasing risk of deteriorating health of the cardiovascular system and brain with age, is important to establish whether healthy aging is associated with changes in plasma $\omega 3$ fatty acid content or response to fortification/supplementation ${ }^{(18)}$ It is becoming increasingly evident that long chain PUFA from the $n-3$ family appears to be neuroprotective and may also have unique properties in affecting neurobiology, both of critical interest during the aging process ${ }^{(19-27)}$. Intake of $n$-3 PUFA has also been associated with potential benefits in other age-related morbidities, including rheumatoid arthritis, depression and macular degeneration. In fact, surprisingly, in both plasma and red blood cells, several studies have reported that the content of eicosapentaenoic acid (EPA) and docosahexaenoic acid (DHA) rises significantly from the second to the seventh decade of life $e^{(28-33)}$. Normally, higher plasma (and red cell) $\omega 3$ fatty acid status in the elderly would seem to be due to higher fish/seafood intake but may also be due to aging-related changes in $\omega 3$ metabolism. However, these findings are not universal, since other studies have found that the intake of polyunsaturated fatty acids decrease with age ${ }^{(34)}$ and most older people eat less that the recommended amounts. In contrast to their proposed actions in childhood, where $n$-3 long-chain polyunsaturated fatty acids are required for healthy development of brain tissue, in older age are more like to act in a protective and healthmaintaining manner. For example, $n-3$ are known to inhibit hepatic triglyceride synthesis and by modifying eicosanoid

*Corresponding author: G. Varela-Moreiras, fax 34-913510496, email gvarela@ceu.es 
function, cause vascular relaxation, a diminished inflammatory process and decrease platelet aggregation ${ }^{(35)}$

Nevertheless, these studies all had important limitations, including a small number of subjects. In addition, although 65 years of age is frequently used as reference, there is no official or widely accepted definition of elderly, so the cut-off used in studies is often as low as 50 years of age. Furthermore, information about the health status, blood chemistry, cognitive function or physical activity of elderly research subjects is rarely given in sufficient detail to establish whether or not the data reported are for the healthy elderly. The main target of the present chapter of the systematic review is based on moderately healthy elderly, based on their active lifestyle, normal cognition and relatively good physical condition.

Ageing physiological process, its association with quality of life and the impact of omega- 3 fatty acids intake and/or status is the focus of the present chapter. Undoubtedly, ageing is linked to several pathological conditions (osteoporosis, sarcopenia, neurodegenerative diseases, etc.) that are not targeted. The main question to be discussed in the present review is: How $\omega 3$ fatty acids may affect the overall diet and quality of life in the elderly people subjects?

\section{Methods}

This report deals with the effects of omega- 3 fatty acids on normal aging of older adults ( $\geq 65$ years) and on their quality of life.

\section{Study identification}

We searched Medline (1966-2011), EMBASE (1980-2011) and LILACS (1982-2011). The terms used and the search strategies were the following:

Fatty Acids, Omega-3/all subheadings
DHA
EPA
Aged
Aged nutrition physiology
Nutritional Status
Diet records
Dietary supplements
Health
Health Status Indicators
Quality of life
Cognition
Cognition disorders
Food, fortified
Bone density
Muscle tonus
Deficiency (subheading)

The search strategies, which were applied in the three databases above mentioned, were as follows:

"Fatty Acids, Omega-3"/all subheadings or "Docosahexaenoic acids (DHA)" or "Eicosapentaenoic acids (EPA)" or "DHA and EPA" and "Aged" or "Aged nutrition physiology" and "Nutritional status" or "Diet records" or "Dietary supplements" or "Health" or "Health Status Indicators" or "Quality of life" or "Cognition" or "Cognition disorders" or "Food, fortified" or "Bone density" or "Muscle tonus" or "Deficiency" (subheading).

The search was not limited by language of publication or study design, in order to increase specificity. The titles and abstract obtained (a total amount of 685) were screened for relevant articles. The full texts of the relevant articles were checked for inclusion criteria $(n=100)$. Our purpose at this initial phase of screening was to identify articles that described studies about the effects of omega-3 fatty acids on normal healthy aging in human subjects and on their quality of life. Therefore, the full text of any articles for which it was not possible to determine relevance from the title and/or abstract was also retrieved for further review. At this point, only titles and/or abstracts that clearly did not meet these criteria for inclusion were rejected $(n=643)$. Two of the investigators (N. U. and M. A.) independently decided which studies met the inclusion criteria. Any differences were resolved by consensus, also by consulting a third reviewer (G. V.) in order to resolve any persisting difference. The flow diagram for screening process is depicted in (Fig. 1). The final number of studies included for the present systematic review was 36 .

\section{Study selection criteria}

Studies were included if they met the following criteria; otherwise they were excluded:

1. The studies reported research on human subjects including at least a group $\geq 65$ years.

2. All participants were healthy elderly people without diagnosis of a pathological condition.

3. The studies were related to the effects derived only from EPA or DHA or EPA plus DHA dietary intakes and/or status, without the presence of other confounding factors such as vitamin or mineral supplements, etc.

4. The studies reported dietary intakes of EPA or DHA or EPA plus DHA from natural food sources and/or fortified

Potentially relevant reports identified and screened for retrieval $(n=685)$

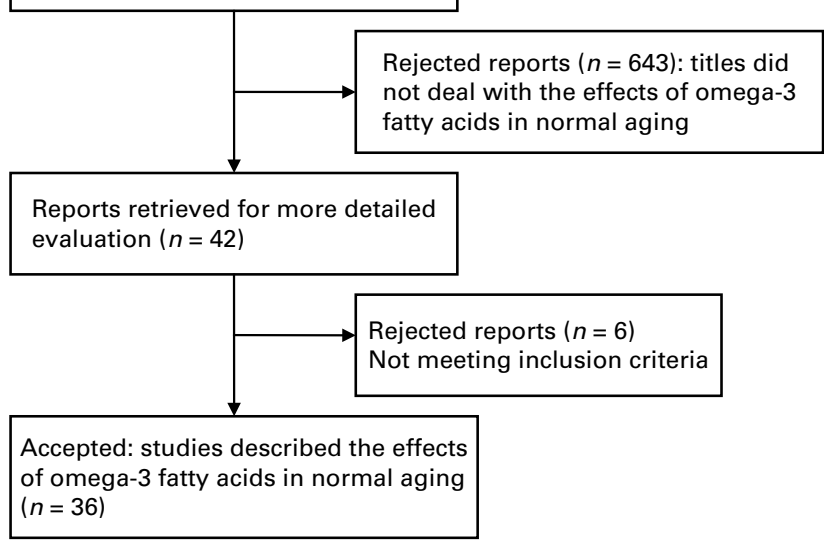

Fig. 1. Flow diagram for screening process. 


\section{N British Journal of Nutrition}

Table 1. Characteristics of identified studies on the effects of omega-3 fatty acids on cognitive function in normal aging

\begin{tabular}{|c|c|c|c|c|c|c|c|c|}
\hline $\begin{array}{l}\text { Authors } \\
\text { year }\end{array}$ & Study design & Population & $\begin{array}{c}\text { Age } \\
\text { (years/range) }\end{array}$ & $\begin{array}{l}\text { Sex } \\
\text { distribution } \\
\% \text { male }\end{array}$ & $\begin{array}{l}\text { Total } \\
\text { sample } \\
\text { size }\end{array}$ & $\begin{array}{l}\text { Study } \\
\text { duration } \\
\text { (months) }\end{array}$ & Outcome measure & Outcome \\
\hline $\begin{array}{l}\text { Kalmijn et al., } \\
(1997)^{(60)}\end{array}$ & Cohort & $\begin{array}{l}\text { Elderly from the Zutphen } \\
\text { Elderly Study }\end{array}$ & $69-89$ & 100 & 476 & 36 & MMSE & $\begin{array}{l}\text { Inverse association between } \\
\text { fish consumption and cogni- } \\
\text { tive impairment (OR: } 0.96 \\
(0.57-1.62) \text { and decline (OR: } \\
0.78(0.35-1.73) \text {. }\end{array}$ \\
\hline $\begin{array}{l}\text { Vakhapova et al., } \\
(2010)^{(61)}\end{array}$ & $\begin{array}{l}\text { Randomized } \\
\text { double-blind } \\
\text { placebo-con- } \\
\text { trolled study }\end{array}$ & $\begin{array}{l}\text { Non-demented elderly with } \\
\text { memory complaints }\end{array}$ & (73) $50-90$ & $50 \cdot 5$ & 131 & 3.5 & $\begin{array}{l}\text { MMSE } \\
\text { RAVLT score } \\
\text { RCFT score }\end{array}$ & $\begin{array}{l}\text { Phosphatidylserine-DHA (PS- } \\
\text { DHA) (300 mg PS and } 79 \text { mg } \\
\text { DHA + EPA 3:1) treatment } \\
\text { improves verbal immediate } \\
\text { memory. Those with higher } \\
\text { baseline cognitive status were } \\
\text { more likely to respond to } \\
\text { treatment. }\end{array}$ \\
\hline $\begin{array}{l}\text { Johnson et al., } \\
(2008)^{62)}\end{array}$ & $\begin{array}{l}\text { Double-blind } \\
\text { intervention } \\
\text { trial }\end{array}$ & Older women & $60-80$ & 0 & 49 & 4 & $\begin{array}{l}\text { Eight different cognitive test } \\
\text { (verbal fluency, digit span for- } \\
\text { ward and backward, shopping } \\
\text { list task, word list memory } \\
\text { test, memory in reality apart- } \\
\text { ment test, NES2 pattern com- } \\
\text { parison test, stroop test, } \\
\text { NES2 mood scales) }\end{array}$ & $\begin{array}{l}\text { Supplementation with } \\
800 \mathrm{mg} / \text { day of DHA improves } \\
\text { verbal fluency. }\end{array}$ \\
\hline $\begin{array}{l}\text { Whalley et al., } \\
(2004)^{(63)}\end{array}$ & $\begin{array}{l}\text { Observational } \\
\text { study }\end{array}$ & $\begin{array}{l}\text { Cohort living independently in } \\
\text { the community }\end{array}$ & 64 & $51 \cdot 1$ & 350 & - & $\begin{array}{l}\text { MMSE } \\
\text { RSPM } \\
\text { RAVLT } \\
\text { WAIS }\end{array}$ & $\begin{array}{l}\text { Dietary fish oil intake and } \\
\text { erythrocyte } n \text { - } 3 \text { content are } \\
\text { associated with better cogni- } \\
\text { tive aging. At the age of } 64 \text { y } \\
\text { food supplements users had } \\
\text { higher digit symbol (mental } \\
\text { speed) results than nonusers, } \\
\text { after adjustment for childhood } \\
\text { IQ. }\end{array}$ \\
\hline $\begin{array}{l}\text { Heude et al., } \\
(2003)^{(64)}\end{array}$ & Cohort & $\begin{array}{l}\text { Cohort from the Etude du } \\
\text { Vieillissement Artériel (EVA) }\end{array}$ & $63-74$ & $47 \cdot 9$ & 246 & 4 & MMSE & $\begin{array}{l}\text { Content total } n-3 \text { fatty acids in } \\
\text { erythrocyte membrane, which } \\
\text { can reflect dietary fat intake, } \\
\text { were inversely associated } \\
\text { with cognitive decline (OR: } \\
0.59 ; 95 \% \mathrm{Cl} \text { : } 0.38-0.93) \text {. } \\
\text { After adjustment, this associ- } \\
\text { ation was significant for DHA } \\
\text { but not for EPA. }\end{array}$ \\
\hline $\begin{array}{l}\text { Vercambre et al., } \\
(2009)^{(37)}\end{array}$ & Cohort & $\begin{array}{l}\text { E3N French longitudinal } \\
\text { cohort }\end{array}$ & $62-68$ & 0 & 4,809 & 156 & $\begin{array}{l}\text { IADL } 7 \\
\text { DECO }\end{array}$ & $\begin{array}{l}\text { Inverse association between } \\
\text { fish consumption and cogni- } \\
\text { tive decline (OR: } 0.80(0.64- \\
0.99) \text { but not significant for } \\
\text { functional impairment (OR: } \\
0.99(0.81-1 \cdot 21) \text {. The same } \\
\text { for } n-3 \text { fatty acids intake: cog- } \\
\text { nitive decline (OR: } 0.79 \\
(0.63-0.98) \text {; functional impair- } \\
\text { ment (OR: } 0.94 \\
(0.77-1.15) \text {. }\end{array}$ \\
\hline
\end{tabular}




\section{N British Journal of Nutrition}

Table 1. Continued

\begin{tabular}{|c|c|c|c|c|c|c|c|c|}
\hline $\begin{array}{l}\text { Authors } \\
\text { year }\end{array}$ & Study design & Population & $\begin{array}{c}\text { Age } \\
\text { (years/range) }\end{array}$ & $\begin{array}{l}\text { Sex } \\
\text { distribution } \\
\% \text { male }\end{array}$ & $\begin{array}{l}\text { Total } \\
\text { sample } \\
\text { size }\end{array}$ & $\begin{array}{l}\text { Study } \\
\text { duration } \\
\text { (months) }\end{array}$ & Outcome measure & Outcome \\
\hline $\begin{array}{l}\text { Velho et al., } \\
(2007)^{(65)}\end{array}$ & $\begin{array}{l}\text { Prospective } \\
\text { study }\end{array}$ & $\begin{array}{l}\text { Free-living elderly from a Por- } \\
\text { tuguese town near Lisbon } \\
\text { (Oeiras) }\end{array}$ & Over 65 & $29 \cdot 4$ & 110 & $8.5 \pm 3.5$ & MMSE & $\begin{array}{l}\text { At follow-up } 57 \% \text { showed a } \\
\text { mild improvement of their } \\
\text { MMSE score. The consump- } \\
\text { tion of } n-3 \text { fatty acids was sig- } \\
\text { nificantly higher than subjects } \\
\text { without improvement. }\end{array}$ \\
\hline $\begin{array}{l}\text { Dullemeijer et al., } \\
(2007)^{(38)}\end{array}$ & $\begin{array}{l}\text { Longitudinal } \\
\text { study and } \\
\text { cross-sec- } \\
\text { tional study }\end{array}$ & $\begin{array}{l}\text { Sample of FACIT trial (pla- } \\
\text { cebo group) }\end{array}$ & $50-70$ & 72 & $\begin{array}{l}807 \text { (cross- } \\
\text { sectional } \\
\text { study) } 404 \\
\text { (longitudinal } \\
\text { study) }\end{array}$ & 36 & $\begin{array}{l}5 \text { cognitive test: Concept } \\
\text { Shifting Test, Stroop Color- } \\
\text { Word Test, Word Learning } \\
\text { Test, Letter Digit Substitution } \\
\text { Test, Verbal Fluency Test } \\
\text { MMSE }\end{array}$ & $\begin{array}{l}\text { Higher plasma proportions of } \\
n-3 \text { fatty acids are associated } \\
\text { with less decline in 3-y cogni- } \\
\text { tive performance in sensori- } \\
\text { motor speed and complex } \\
\text { speed but not in memory, } \\
\text { information-processing speed } \\
\text { and word fluency. }\end{array}$ \\
\hline $\begin{array}{l}\text { Laurin et al., } \\
(2003)^{(41)}\end{array}$ & $\begin{array}{l}\text { Longitudinal } \\
\text { study and } \\
\text { cross-sec- } \\
\text { tional study }\end{array}$ & $\begin{array}{l}\text { Population of the Canadian } \\
\text { Study of Health and Aging }\end{array}$ & $>65$ & $?$ & 122 & 60 & Zaudig's criteria & $\begin{array}{l}\text { In the cross-sectional anal- } \\
\text { ysis, no significant difference } \\
\text { in omega-3 PUFA concen- } \\
\text { tration was observed between } \\
\text { controls and cases of cogni- } \\
\text { tive imparirment. In the pro- } \\
\text { spective analysis a higher } \\
\text { EPA concentration was found } \\
\text { in cognitively impaired cases } \\
\text { compared to controls. }\end{array}$ \\
\hline $\begin{array}{l}\text { Dangour et al., } \\
(2010)^{(24)}\end{array}$ & $\begin{array}{l}\text { Randomized, } \\
\text { double-blind, } \\
\text { controlled } \\
\text { trial (OPAL } \\
\text { study) }\end{array}$ & $\begin{array}{l}\text { Cognitively healthy adults } \\
\text { from } 20 \text { general practices in } \\
\text { England and Wales }\end{array}$ & $75(70-79)$ & 55 & 748 & 24 & CVLT & $\begin{array}{l}\text { No evidence of a beneficial } \\
\text { effect of fish oil supplemen- } \\
\text { tation ( } 200 \mathrm{mg} \text { EPA plus } \\
500 \mathrm{mg} \text { DHA) on cognitve } \\
\text { function in older people. } \\
\text { There was no change in cog- } \\
\text { nitive function scores over } \\
24 \text { mo, and intention-to-treat } \\
\text { analysis showed no significant } \\
\text { differences between trial arms } \\
\text { at } 24 \text { mo in the CVLT or any } \\
\text { secondary cognitive outcome. }\end{array}$ \\
\hline $\begin{array}{l}\text { Yurko-Mauro } \\
\text { et al., }(2010)^{(66)}\end{array}$ & $\begin{array}{l}\text { Randomized, } \\
\text { double-blind, } \\
\text { placebo con- } \\
\text { trolled trial }\end{array}$ & $\begin{array}{l}\text { Subjects enrolled at } 19 \text { sites in } \\
\text { the United States }\end{array}$ & Over 55 & 42 & 485 & 6 & $\begin{array}{l}\text { CANTAB PAL } 6 \\
\text { CANTAB VRM } \\
\text { CANTAB SOC } \\
\text { CANTAB SWM }\end{array}$ & $\begin{array}{l}\text { Supplementation with } \\
900 \mathrm{mg} / \mathrm{d} \mathrm{DHA} \text { improved } \\
\text { learning and memory function } \\
\text { in ARCD and is a beneficial } \\
\text { supplement that supports cog- } \\
\text { nitive health with aging. }\end{array}$ \\
\hline
\end{tabular}


Table 1. Continued

\begin{tabular}{|c|c|c|c|c|c|c|c|c|}
\hline $\begin{array}{l}\text { Authors } \\
\text { year }\end{array}$ & Study design & Population & $\begin{array}{c}\text { Age } \\
\text { (years/range) }\end{array}$ & $\begin{array}{l}\text { Sex } \\
\text { distribution } \\
\% \text { male }\end{array}$ & $\begin{array}{l}\text { Total } \\
\text { sample } \\
\text { size }\end{array}$ & $\begin{array}{l}\text { Study } \\
\text { duration } \\
\text { (months) }\end{array}$ & Outcome measure & Outcome \\
\hline $\begin{array}{l}\text { Van Gelder et al., } \\
(2007)^{(77)}\end{array}$ & Cohort & $\begin{array}{l}\text { Elderly from the Zutphen } \\
\text { Elderly Study }\end{array}$ & $70-89$ & 100 & 210 & 60 & MMSE & $\begin{array}{l}\text { Fish consumers had signifi- } \\
\text { cantly less } 5 \text { y subsequent } \\
\text { cognitive decline than did non- } \\
\text { consumers. An average differ- } \\
\text { ence of } \approx 400 \mathrm{mg} / \mathrm{d} \text { in } \\
\text { EPA }+ \text { DHA intake was } \\
\text { associated with a } 1 \cdot 1 \text {-point } \\
\text { significant difference in cogni- } \\
\text { tive decline. }\end{array}$ \\
\hline $\begin{array}{l}\text { González et al., } \\
(2010)^{(67)}\end{array}$ & $\begin{array}{l}\text { Cross-sec- } \\
\text { tional }\end{array}$ & $\begin{array}{l}\text { Institutionalized elderly popu- } \\
\text { lation of Asturias (Spain) }\end{array}$ & $75 \cdot 3 \pm 6 \cdot 7$ & 41.7 & 304 & - & MMSE & $\begin{array}{l}\text { Higher } n-3 \text { fatty acids intake } \\
\text { are higher in the group of } \\
\text { elderly with a better cognitive } \\
\text { score (MMSE }>24 \text { ). }\end{array}$ \\
\hline $\begin{array}{l}\text { Van de Rest } \\
\text { et al., }(2008)^{(39)}\end{array}$ & $\begin{array}{l}\text { Randomized, } \\
\text { double-blind, } \\
\text { placebo con- } \\
\text { trolled trial }\end{array}$ & $\begin{array}{l}\text { Healthy subjects aged }>65 \\
\text { years recruited of a database } \\
\text { of volunteers with interest in } \\
\text { participating in studies at } \\
\text { Wageningen University. }\end{array}$ & 70 & 55 & 302 & $6 \cdot 5$ & $\begin{array}{l}\text { MMSE } \\
5 \text { cognitive test: Trail Making } \\
\text { Test, Stroop Color-Word Test, } \\
\text { Word Learning Test, Wechs- } \\
\text { ler Digit Span Task Test, Ver- } \\
\text { bal Fluency Test }\end{array}$ & $\begin{array}{l}\text { There were no significant } \\
\text { differential changes in any of } \\
\text { the cognitive domains for } \\
\text { either low-dose fish oil sup- } \\
\text { plementation compared with } \\
\text { placebo. }\end{array}$ \\
\hline $\begin{array}{l}\text { Richter et al., } \\
(2010)^{(68)}\end{array}$ & $\begin{array}{l}\text { Single-center, } \\
\text { open-label } \\
\text { study }\end{array}$ & $\begin{array}{l}\text { Volunteers aged }>60 \text { years } \\
\text { with subjective memory com- } \\
\text { plaints from Haifa, Israel. }\end{array}$ & $69 \cdot 3$ & 37.5 & 8 & 1.5 & $\begin{array}{l}\text { Cognitive Drug Research } \\
\text { (CDR) that includes nine sep- } \\
\text { arate tasks and five compo- } \\
\text { site factors calculated from } \\
\text { the results on the single } \\
\text { tasks. }\end{array}$ & $\begin{array}{l}\text { PS-omega-3 ( } 37.5 \mathrm{mg} \text { EPA + } \\
\text { DHA) may have a favourable } \\
\text { effect on memory recall ( } 42 \% \\
\text { of increase) in subjects with } \\
\text { subjective memory com- } \\
\text { plaints, specifically on the } \\
\text { ability to store, hold, and } \\
\text { retrieve information of an epi- } \\
\text { sodic nature. }\end{array}$ \\
\hline $\begin{array}{l}\text { Lauretani et al., } \\
(2007)^{(69)}\end{array}$ & Cohort & $\begin{array}{l}\text { Population aging in Chianti } \\
\text { area (Italy). InCHIANTI study. }\end{array}$ & $\begin{array}{l}68 \cdot 2 / \text { Different } \\
\text { groups ( } 3 \\
\text { groups over } \\
65 \mathrm{y})\end{array}$ & 46.4 & 827 & 3 & $\begin{array}{l}\text { Studies of the right peroneal } \\
\text { nerve (ENG-neuro MYTO } \\
\text { device) }\end{array}$ & $\begin{array}{l}\text { DHA predicted significantly } \\
\text { less decline of nerve conduc- } \\
\text { tion velocity (NCV) in partici- } \\
\text { pants older than } 85 \text { years of } \\
\text { age. Omega-3 fatty acids and } \\
\text { DHA predicted significantly } \\
\text { less decline in compound } \\
\text { muscle action potential } \\
\text { (CMAP) in participants } \\
\text { between } 65 \text { and } 84 \text { years old. }\end{array}$ \\
\hline $\begin{array}{l}\text { Van de Rest } \\
\text { et al., }(2009)^{(42)}\end{array}$ & $\begin{array}{l}\text { Longitudinal } \\
\text { study and } \\
\text { cross-sec- } \\
\text { tional study }\end{array}$ & $\begin{array}{l}\text { Participants were from the } \\
\text { Veterans Affairs Normative } \\
\text { Aging Study }\end{array}$ & 68 & 100 & $\begin{array}{l}1025 \text { (cross- } \\
\text { sectional } \\
\text { study) } 313 \\
\text { (longitudinal } \\
\text { study) }\end{array}$ & 72 & $\begin{array}{l}\text { Battery of cognitive test } \\
\text { (memory/language, speed, } \\
\text { visuospatial/attention) }\end{array}$ & $\begin{array}{l}\text { Cross-sectional analyses } \\
\text { showed no association } \\
\text { between fatty fish or }(n-3) \\
\text { PUFA intake and cognitive } \\
\text { performance. Longitudinal } \\
\text { analyses also did not show } \\
\text { any significant associations } \\
\text { fatty fish or ( } n-3) \text { PUFA intake } \\
\text { and cognitive change. }\end{array}$ \\
\hline
\end{tabular}




\section{N British Journal of Nutrition}

Table 1. Continued

\begin{tabular}{|c|c|c|c|c|c|c|c|c|}
\hline $\begin{array}{l}\text { Authors } \\
\text { year }\end{array}$ & Study design & Population & $\begin{array}{c}\text { Age } \\
\text { (years/range) }\end{array}$ & $\begin{array}{l}\text { Sex } \\
\text { distribution } \\
\% \text { male }\end{array}$ & $\begin{array}{l}\text { Total } \\
\text { sample } \\
\text { size }\end{array}$ & $\begin{array}{l}\text { Study } \\
\text { duration } \\
\text { (months) }\end{array}$ & Outcome measure & Outcome \\
\hline $\begin{array}{l}\text { Roberts et al., } \\
(2010)^{(70)}\end{array}$ & $\begin{array}{l}\text { Cross-sec- } \\
\text { tional }\end{array}$ & $\begin{array}{l}\text { Population of the Rochester } \\
\text { epidemiology Project, from } \\
\text { Olmsted County, MN, USA. }\end{array}$ & $70-89$ & 55.5 & 1233 & - & $\begin{array}{l}\text { CDR + Nine test in four cog- } \\
\text { nitive domains: memory, } \\
\text { executive function, language } \\
\text { and visuospatial skills. }\end{array}$ & $\begin{array}{l}\text { The OD of mild cognitive } \\
\text { impairment (MCI) decreased } \\
\text { with increasing PUFA intake. } \\
\text { The OD ( } 95 \% \text { confidence } \\
\text { interval) were } 0.62 \text { ( } 0.42- \\
0.91) \text { for omega- } 3 \text { fatty acids. }\end{array}$ \\
\hline $\begin{array}{l}\text { Matsumoto et al. } \\
(2009)^{(71)}\end{array}$ & Cohort & $\begin{array}{l}\text { Community-dwellers recruited } \\
\text { in two separate towns in Shi- } \\
\text { mane (Japan) }\end{array}$ & $>65$ & $?$ & 54 & 48 & $\begin{array}{l}\text { Hasegawa dementia rating } \\
\text { scale (HDS) }\end{array}$ & $\begin{array}{l}\text { Subjects who showed } \\
\text { improvements or no change in } \\
\text { their HDS results consumed } \\
\text { more DHA than those whose } \\
\text { HDS results worsened. }\end{array}$ \\
\hline $\begin{array}{l}\text { Ortega et al., } \\
(1997)^{(40)}\end{array}$ & $\begin{array}{l}\text { Cross-sec- } \\
\text { tional }\end{array}$ & $\begin{array}{l}\text { Noninstitutionalized elderly } \\
\text { people from Madrid (Spain) }\end{array}$ & $65-90$ & 41.5 & 260 & - & $\begin{array}{l}\text { MMSE } \\
\text { PMSQ }\end{array}$ & $\begin{array}{l}\text { No significant difference in } \\
\text { PUFA intake between unsatis- } \\
\text { factory responders in test and } \\
\text { satisfactory. }\end{array}$ \\
\hline $\begin{array}{l}\text { Requejo et al., } \\
(2003)^{(72)}\end{array}$ & $\begin{array}{l}\text { Cross-sec- } \\
\text { tional }\end{array}$ & $\begin{array}{l}\text { Independently living elderly } \\
\text { people from Madrid (Spain) }\end{array}$ & $65-90$ & $?$ & 168 & - & MMSE & $\begin{array}{l}\text { Subjects with an adequate } \\
\text { cognitive capacity showed } \\
\text { greater intake of fish. }\end{array}$ \\
\hline $\begin{array}{l}\text { Kesse-Guyot } \\
\text { et al., }(2011)^{(73)}\end{array}$ & Cohort & $\begin{array}{l}\text { Population of the SU.VI.MAX } \\
\text { study }\end{array}$ & & $?$ & 3294 & 156 & $\begin{array}{l}\text { Cognitive test and self- } \\
\text { reported cognitive difficulties } \\
\text { scale }\end{array}$ & $\begin{array}{l}\text { Self-reported cognitive difficul- } \\
\text { ties were less frequent among } \\
\text { subjects with higher intakes of } \\
\text { total } n-3 \text { long chain fatty acids } \\
\text { (OR }=0.72,0.56-0.92 \text { ) and } \\
\text { EPA (OR Q4 versus } \\
\text { Q1 }=0.74,0.58-0.95 \text { ). }\end{array}$ \\
\hline $\begin{array}{l}\text { Conquer et al., } \\
(2000)^{(74)}\end{array}$ & $\begin{array}{l}\text { Cross-sec- } \\
\text { tional }\end{array}$ & & $77-83$ & $?$ & 55 & - & 6 cognitive test & $\begin{array}{l}\text { Lower } n \text {-3 PUFA concen- } \\
\text { trations in cognitively impaired } \\
\text { group. }\end{array}$ \\
\hline $\begin{array}{l}\text { Kalmijn et al., } \\
(2004)^{(75)}\end{array}$ & $\begin{array}{l}\text { Cross-sec- } \\
\text { tional }\end{array}$ & & $45-70$ & $?$ & 1613 & - & $\begin{array}{l}\text { Test in cognitive domains: } \\
\text { memory, psychomotor speed, } \\
\text { cognitive flexibility and overall } \\
\text { cognition. }\end{array}$ & $\begin{array}{l}\text { Marine } n-3 \text { PUFA were inver- } \\
\text { sely related to the risk of } \\
\text { impaired overall cognitive } \\
\text { function and speed } \\
(\mathrm{OR}=0.81,0.72-0.90) \text {. } \\
\text { Results for fatty fish consump- } \\
\text { tion were similarly inverse. }\end{array}$ \\
\hline $\begin{array}{l}\text { Morris et al., } \\
(2005)^{(76)}\end{array}$ & $\begin{array}{l}\text { Prospective } \\
\text { cohort study }\end{array}$ & $\begin{array}{l}\text { Community from Chicago. } \\
\text { Chicago Health and Aging } \\
\text { Project. }\end{array}$ & $>65$ & $?$ & 3718 & 72 & 4 standardized tests & $\begin{array}{l}\text { Higher fish intake, but not } n-3 \\
\text { PUFA intake, associated with } \\
\text { slower cognitive decline. }\end{array}$ \\
\hline $\begin{array}{l}\text { Beydoun et al., } \\
(2007)^{(20)}\end{array}$ & $\begin{array}{l}\text { Prospective } \\
\text { cohort study }\end{array}$ & $\begin{array}{l}\text { Volunteers from Minneapolis. } \\
\text { ARIC study. }\end{array}$ & $50-65$ & $49 \cdot 3$ & 2251 & 72 & $\begin{array}{l}\text { DWRT } \\
\text { DSST/WAIS-R } \\
\text { WFT }\end{array}$ & $\begin{array}{l}\text { Higher } n \text {-3 PUFA concen- } \\
\text { trations associated with lower } \\
\text { risk of decline in verbal flu- } \\
\text { ency. } \mathrm{RCl}<-1.645 \text {. }\end{array}$ \\
\hline
\end{tabular}

II E : Mest, RCFT: Rey Complex Figure Test, RSPM: Raven's Standard Progrossive Matices; WAIS: Wochsler Adul In Instrumental Activities of Daily Living; DECO: Deterioration Cognitive Observee (observed cognitive deterioration); CVLT: California Verbal Learning Test; CANTAB PAL 6: visuospatial learning and episodic memory test;

Digit Symbol Substitution Test of the Wechler Adult Intelligence Scale-revised; WFT: Word Fluency Test 
foods and/or supplements. The supplements (if applied) could be taken with any dose or duration.

5. All categories of epidemiological studies were included.

6. The dietary assessment included a validated methodology, regardless of the tool.

7. The studies informing of the nutritional status included also the standardized method utilized

To increase the generalization of the results, no restrictions were established on participants' baseline nutritional status or other study settings (community dwelling, participants on their own ...)

\section{Types of outcomes}

We focused on the effects of omega- 3 fatty acids on the main aspects derived from the impairment in the quality of life that is unavoidably associated to normal and physiological aging, such as nutritional status itself, cognition, bone health, muscle tonus, and general health status.

\section{Data Extraction and quality assessment}

Data were collected from each article for authors and year of publication, study design, population, age, sex distribution, total sample size, duration, outcomes of interest (Table 1).

Information about the methodological quality of the studies was also abstracted. One author abstracted the data by using an internal data extraction form, and another one checked the accuracy. A 10-item quality appraisal form, based on the one used by Avenell \& Handoll $(2005)^{(36)}$, was used to assess the methodological quality of each included study. The 10 items included the concealment of randomization, intention-to-treat-analysis, blinding of participants, treatment provider and assessor, comparability of groups at entry, identical care programmes, the specification of inclusion and exclusion criteria, definition of the intervention, the overall duration, appropriateness of the follow up, and withdraws.

\section{Data Analysis/Statistics}

Due to the heterogeneity among studies, very few studies met the inclusion criteria. Therefore, it was not possible to perform a meta-analysis. The overall effects of omega-3 fatty acids within the studies are described. The point estimates and statistical testing that were described in the original studies are summarized.

\section{Results}

The effects of omega- 3 fatty acids on normal aging that we summarize as follows are those reported within the 36 studies that were finally included in the present review. According to the quality scale used, all the trials got a score range of $12-20$ (20 was the possible maximum score). All the trials were conducted in "developed" countries, and academic institutes or national organizations supported all of them. None reported pharmaceutical company and/or food industry funding.

\section{Effects of omega-3 fatty acid on cognitive function in normal aging}

We have retrieved a total of 26 articles that evaluated the effects of omega-3 fatty acids on cognitive function in normal aging and healthy older people. Thirteen were longitudinal studies, ten were cross-sectional (three of them included longitudinal and cross-sectional analysis) and six were randomized, double-blind controlled trials. All of the studies used the Mini Mental State Examination (MMSE) to evaluate global cognitive function which include questions about orientation to time and place, registration, attention and calculation, recall, language, etc and/or other specific test (e.g. verbal fluency, speed, visuospatial skills, etc). Most of them considered cognitive impairment as a MMSE score $<25$ and cognitive decline was defined as a drop of more than two points in the MMSE over the period studied; however, cognitive decline is defined uniquely according to each study, and thus comparing outcomes across studies must be interpreted with caution. One analyzed specifically changes in the nerve conduction velocity and compound muscle action potential. The content of omega-3 fatty acid was evaluated through dietary information (intake of fish or DHA/EPA) with appropriate questionnaires or concentration in plasma and/or erythrocyte membrane. The characteristics of the studies that were analyzed are described in Table 1.

Nineteen of all articles showed a positive relationship between an adequate fish consumption or $n-3$ fatty acids intake (diet or supplements) or total content in erythrocyte membrane and cognitive status or less cognitive decline during aging. These results are promising and encourage further research in order to establish a safe and effective treatment solution for cognitive impairment and subsequently disability in elderly population. Promoting higher intakes of $n-3$ PUFA in the diet or specifics supplements may have substantial benefits in reducing their risk of cognitive decline. However, authors concluded that further studies are warranted to confirm and evaluate theses potential positive effects.

Two of the articles showed some improvements but other measures remained unchanged. Vercambre et al. ${ }^{(37)}$ observed an inverse association between fish consumptions and $n-3$ fatty acids intake and cognitive decline but not significant for functional impairment. Dullemeijer et al. ${ }^{(38)}$ concluded that higher plasma proportions of $n$ - 3 fatty acids are associated with less decline cognitive performance in sensorimotor speed and complex speed but not in memory, information-processing speed and word fluency.

Five of the studies showed no positive effects of $n-3$ fatty acids in cognitive function. Two RCTs ${ }^{(24,39)}$ used high doses or EPA plus DHA and olive oil or oleic acid as placebo but did not find significant changes in any cognitive domains over 6 and 24 months, respectively. Both of them recommended that further longer trials should be conducted. Three cross-sectional studies ${ }^{(40-42)}$ showed no significant differences in $n$ - 3 PUFA intake between controls and cases of cognitive decline/impairment, and two of them ${ }^{(41,42)}$ also did not show any significant associations between fatty fish 
Table 2. Characteristics of identified studies on the effects of omega-3 fatty acids on immune function in normal aging

\begin{tabular}{|c|c|c|c|c|c|c|c|c|}
\hline $\begin{array}{l}\text { Authors } \\
\text { year }\end{array}$ & Study design & Population & $\begin{array}{l}\text { Age } \\
\text { (years/range) }\end{array}$ & $\begin{array}{l}\text { Sex } \\
\text { distribution\% } \\
\text { male }\end{array}$ & $\begin{array}{l}\text { Total } \\
\text { sample } \\
\text { size }\end{array}$ & $\begin{array}{l}\text { Study dur- } \\
\text { ation } \\
\text { (months) }\end{array}$ & Outcome measure & Outcome \\
\hline $\begin{array}{l}\text { Bechoua et al. } \\
(2003)^{(44)}\end{array}$ & $\begin{array}{l}\text { Randomized } \\
\text { double-blind }\end{array}$ & $\begin{array}{l}\text { Healthy non-institu- } \\
\text { tionalized elderly } \\
\text { people }\end{array}$ & $70-83$ & 30 & 20 & 1.5 & $\begin{array}{l}\text { Lymphocyte proliferation } \\
\text { Biochemical markers known } \\
\text { to be altered with age (PDE, } \\
\text { phosphodiesterase activity; } \\
\text { GSH-Px, Glutathione peroxi- } \\
\text { dase activity) }\end{array}$ & $\begin{array}{l}\text { The intake of low doses of } n-3 \\
\text { fatty acids }(30 \mathrm{mg} \\
\text { EPA }+150 \mathrm{mg} \text { DHA/d) } \\
\text { decreased the lymphoproli- } \\
\text { ferative responses of elderly } \\
\text { people to mitogens. } \\
\text { PDE and GSH-Px activities } \\
\text { were also modified by this low } \\
\text { EPA + DHA supplementation. }\end{array}$ \\
\hline Thies et al. $(2001)^{(43)}$ & $\begin{array}{l}\text { Randomized, pla- } \\
\text { cebo-controlled, } \\
\text { double blind, } \\
\text { parallel }\end{array}$ & $\begin{array}{l}\text { White elderly people } \\
\text { living in their own } \\
\text { homes }\end{array}$ & $56-74$ & $52 \cdot 1$ & 46 & 3 & Natural Killer (NK) cell activity & $\begin{array}{l}\text { A moderate amount of EPA } \\
\text { but no other } n-3 \text { polyunsatu- } \\
\text { rated fatty acids can decrease } \\
\text { NK cell activity (in a reversible } \\
\text { way) in healthy elderly sub- } \\
\text { jects. }\end{array}$ \\
\hline Thies et al. $(2001)^{(46)}$ & $\begin{array}{l}\text { Randomized, pla- } \\
\text { cebo-controlled, } \\
\text { double blind, parallel }\end{array}$ & $\begin{array}{l}\text { White elderly people } \\
\text { living in their own } \\
\text { homes }\end{array}$ & $55-75$ & $52 \cdot 1$ & 46 & 1.5 & $\begin{array}{l}\text { Lymphocyte proliferation } \\
\text { Production of interleukins }\end{array}$ & $\begin{array}{l}\text { A moderate level of EPA but } \\
\text { no other } n-3 \text { polyunsaturated } \\
\text { fatty acids can decrease lym- } \\
\text { phocyte proliferation but not } \\
\text { the production of interleukin- } 2 \\
\text { or interferon- } \gamma \text {. }\end{array}$ \\
\hline Rees et al. $(2006)^{(31)}$ & $\begin{array}{l}\text { Controlled, double } \\
\text { blind }\end{array}$ & $\begin{array}{l}\text { Healthy voluntary } \\
\text { older men (vs } \\
\text { younger subjects) }\end{array}$ & $53-70$ & 100 & 62 & 3 & $\begin{array}{l}\text { Plasma and mononuclear } \\
\text { cells (MNC) phospholipids } \\
\text { composition } \\
\text { Phagocytic activity and respir- } \\
\text { atory burst }\end{array}$ & $\begin{array}{l}\text { Older subjects incorporate } \\
\text { EPA into plasma and MNC } \\
\text { phospholipids more readily } \\
\text { than do younger subjects. } \\
\text { Older subjects are more } \\
\text { sensitive to the immunologic } \\
\text { effects of EPA, and the neu- } \\
\text { trophil respiratory burst is } \\
\text { lower at higher EPA intakes. }\end{array}$ \\
\hline $\begin{array}{l}\text { Wardwell et al. } \\
(2008)^{(45)}\end{array}$ & $\begin{array}{l}\text { Cross-sectional and } \\
\text { longitudinal }\end{array}$ & $\begin{array}{l}\text { Independently com- } \\
\text { munity living males } \\
\text { and females from the } \\
\text { Champaign (Illinois) } \\
\text { neighbourhood. }\end{array}$ & $65-80$ & 39.3 & 89 & $\begin{array}{l}\text { Not } \\
\text { reported }\end{array}$ & $\mathrm{T}$ cell proliferation & $\begin{array}{l}\text { EPA from diet and sup- } \\
\text { plements was associated with } \\
\text { PHA-induced proliferative } \\
\text { responses }\end{array}$ \\
\hline
\end{tabular}


or $n$-3 PUFA intake and cognitive change over 5 and 6 years, respectively.

More prospective studies, as well as interventions studies investigating the association between $n-3$ PUFA and domainspecific measures are needed to clarify the current conflicting results observed in the literature.

\section{Effects of omega-3 fatty acids on immune function in normal aging}

A total of five studies (four RCT and one cross sectional and longitudinal) examining the effect of omega- 3 fatty acids on immune function (Table 2) were included. All four RCT studies assessed the effect of moderate dietary supplementation with omega-3 fatty acids (EPA or EPA + DHA) on immune biomarkers known to be altered in normal healthy aging. Even very low doses of $n-3$ fatty acids resulted in significantly decreased proliferative responses of lymphocytes in two of the studies ${ }^{(43-44)}$. In one of them ${ }^{(44)}$, also, this was accompanied by a marked significant $(P<0.05)$ increase of their particulate PDE activity (+56-57\%) and an increase $(P<0.05)$ in cyclic nucleotide intracellular levels. At the same time, the glutathione peroxidase activity was markedly depressed $(P<0 \cdot 01)$. The cross sectional study, on the contrary ${ }^{(45)}$, reported significant positive correlations $(P<0.05)$ between PHA-induced proliferation and intake of DHA and EPA. However, these authors state that intakes of DHA plus EPA were inadequate for the studied population when compared to recommended intakes. They also suggest that dietary EPA in vivo might interact differently compared to in vitro studies where EPA is added to cell cultures.

On the other hand, a moderate amount of extra supplementary EPA $(720 \mathrm{mg})$ resulted in a decrease of NK cell activity in the same elderly population ${ }^{(46)}$. This decline (48\%) was fully reversed by 4 weeks after supplementation had ceased.

The effects of different amounts of EPA on innate immune outcomes in older males compared to young were also evaluated $^{(31)}$. EPA was incorporated in a linear dose-response fashion into plasma and mononuclear cell (MNC) phospholipids; incorporation was greater in the older men. This increased incorporation was associated with decreased production of prostaglandin $\mathrm{E}_{2}$ by MNCs. Also, EPA treatment caused a dose-dependent decrease in neutrophil respiratory burst only in the older men.

These five above mentioned studies therefore suggest that even very low doses of omega-3 fatty acids may be sufficient to affect the immune responses of elderly subjects.

\section{Effects of omega-3 fatty acids on bone health and muscle} tonus in normal non-pathological aging

In total, three studies were identified that described the effects of omega-3 fatty acids on bone health or muscle tonus with normal aging; one was a RCT and two were cohort studies. The characteristics of the studies that were analyzed are described in Table 3. The three of them described positive outcomes derived from both dietary and supplemental omega-3 fatty acid intakes on aging.

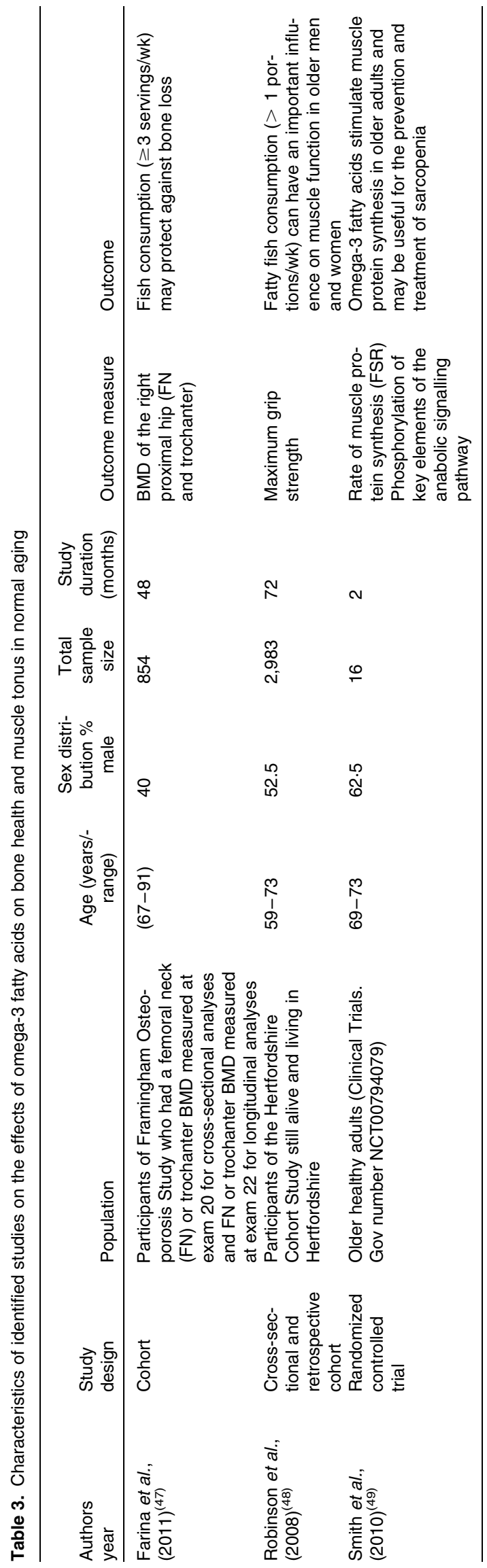


A single cohort study ${ }^{(47)}$ that evaluated the effects of omega3 fatty acids on bone health in aging was identified. This study investigated the associations between dietary polyunsaturated fatty acid and fish intakes and hip bone mineral density (BMD) at baseline (1988-1989, $n=854)$ and changes 4 year later in individuals $(n=623)$ with a mean age of 75 years in the Framingham Osteoporosis. High intakes ( $>3$ servings/wk) of fish relative to lower intakes were associated with maintenance of femoral neck BMD (FN-BMD) in men (dark fish + tuna, dark fish, and tuna) and in women (dark fish) $(P<0.05)$, thus suggesting that fish consumption may protect against bone loss. This study was adjusted for confounders, used valid methods to measure outcomes, and described withdrawals and dropouts.

Two studies that assessed the effect of omega- 3 fatty acids on muscle tonus in normal aging were identified. The cohort study ${ }^{(48)}$ examined the relationships between diet (fatty fish consumption) and grip strength in older men and women living in their own homes. Of the dietary factors considered in relation to grip strength, the most important was fatty fish consumption. An increase in grip strength of $0.43 \mathrm{~kg}(95 \%$ confidence interval $\mathrm{CI}=0.13-0.74)$ in men $(P=0.005)$ and $0.48 \mathrm{~kg}(95 \% \mathrm{CI}=0 \cdot 24-0.72)$ in women $(P<0.001)$ was observed for each additional portion of fatty fish consumed per week. Only one RCT study evaluating the effect of omega-3 fatty acids in muscle tonus in normal aging was retrieved ${ }^{(49)}$. The objective was to evaluate the effect of omega-3 fatty acid supplementation for 8 weeks on the rate of muscle protein synthesis in elderly population (69- 73 years). Omega-3 fatty acid supplementation (1.86g EPA and $1.50 \mathrm{~g}$ DHA) augmented the hyperaminoacidemiahyperinsulinemia-induced increase in the rate of muscle protein synthesis (from $0.009 \pm 0.005 \% / \mathrm{h}$ above basal values to $0.031 \pm 0.003 \% / \mathrm{h}$ above basal values; $P<0.01$ ), which was accompanied by greater increases in muscle $\mathrm{mTOR}^{\mathrm{Ser} 2448}$ $(P=0.08)$ and $\mathrm{p} 70 \mathrm{~s} 6 \mathrm{k}^{\mathrm{Thr} 389}(P<0.01)$ phosphorylation, two elements of intramuscular signal transduction proteins involved in the regulation of muscle protein synthesis. The authors of these two studies suggest that these important influences on muscle function in older men and women raise the possibility that omega- 3 fatty acids may be useful for the prevention and treatment of sarcopenia.

\section{Effects of omega-3 fatty acids on quality of life and mortality in normal aging}

Two single studies (both of them RCT) assessed the influence of omega-3 fatty acids in the quality of life of normal aging (Table 4). Moreover, the baseline characteristics of the population of the two studies were the same, 302 independently living older individuals. The studies differed in the outcomes measured $^{(50,51)}$. The first one investigated the effect of EPA and DHA $(1800 \mathrm{mg} / \mathrm{d} \mathrm{EPA}+\mathrm{DHA}, 400 \mathrm{mg} / \mathrm{d}$ EPA or placebo, for $26 \mathrm{wk}$ ) on mental well-being. The second one evaluated the effect on physical health, psychological health, social relationships and satisfaction with environment through the World Health Organization Quality of Life questionnaire (WHOQOL).
Plasma concentrations of EPA + DHA increased by $238 \%$ in the high-dose and $51 \%$ in the low dose fish-oil group, compared with the placebo group, reflecting excellent compliance. However, treatment with neither $1800 \mathrm{mg}$ nor $400 \mathrm{mg}$ differentially affected any of the measures and geriatric scales of mental well being. Following the same pattern, median baseline total WHOQOL scores ranged from 107 to 110 in the three groups and were not significantly different from each other. Treatment with $1800 \mathrm{mg}$ o $400 \mathrm{mg}$ EPADHA did not affect total Quality of Life questionnaire (QOL) or any of its separate domains after 26 weeks of intervention. For the interpretation of these results, however, it is quite interesting to note that the placebo capsules contained mainly oleic acid.

Two studies estimating the effect of omega-3 fatty acid on mortality in healthy aging were retrieved (Table 4). Folsom and Demissie ${ }^{(52)}$ investigated the diet of a group of 720 postmenopausal women with low cancer and coronary heart disease risk. There was an inverse age- and energy-adjusted association between total mortality and fish intake, with a relative risk of 0.82 (95\% confidence interval: $0.74,0.91$ ) for the highest versus lowest quintile. Estimated marine omega-3 fatty acid intake was not associated with total or cause-specific mortality. A recent intervention study ${ }^{(53)}$ showed results similar to those above mentioned. A group of elderly men $(n=282)$ received a total of $2.4 \mathrm{~g} n-3$ PUFA in two capsules twice daily (49\% EPA and 35\% DHA) for 36 months. The authors observed in this supplemented population a tendency toward reduction in all-cause mortality that, despite the low number of participants, reached almost statistical significance $(P=0.063)$.

\section{Discussion}

In the present review we examined the effect of omega-3 fatty acids on different aspects which modulates the quality of life and the abilities to manage for a better life in aging. We finally included thirty-six articles that analyzed parameters related to cognitive decline, bone health and muscle tonus, immune function and general quality of life and mortality.

Results of the present systematic review suggest that the omega-3 fatty acids may have substantial benefits in reducing the risk of cognitive decline in older people, although there were five studies with no positive effects. The variability in outcomes between human studies which are confounded by methodological differences (type of food frequency questionnaire, test to measure cognitive decline, design of the study, etc), make it difficult for conclusions to be made at this time.

Two RCTs of the five negative studies used as placebo olive oil or oleic acid. Recently, Rosales ${ }^{(54)}$ has published a letter in which explained the possible weakness in these studies. For example, as indicated by the authors, the study population might already consume a sufficient amount of PUFA in their diets and thus not be sensitive to the dose of DHA/EPA provided, but they have also rejected that control group might result in maintaining cognitive function in later life, comparable to the effects of DHA/EPA, because they consumed an extra amount of oleic acid (olive oil) which could provided 
Table 4. Characteristics of identified studies on the effects of omega-3 fatty acids on quality of life and mortality in normal aging

\begin{tabular}{|c|c|c|c|c|c|c|c|c|}
\hline $\begin{array}{l}\text { Authors } \\
\text { year }\end{array}$ & Study design & Population & $\begin{array}{l}\text { Age (years/- } \\
\text { range) }\end{array}$ & $\begin{array}{l}\text { Sex distri- } \\
\text { bution \% } \\
\text { male }\end{array}$ & $\begin{array}{l}\text { Total } \\
\text { sample } \\
\text { size }\end{array}$ & $\begin{array}{l}\text { Study } \\
\text { duration } \\
\text { (months) }\end{array}$ & Outcome measure & Outcome \\
\hline $\begin{array}{l}\text { Van de Rest et al. } \\
(2008)^{(50)}\end{array}$ & $\begin{array}{l}\text { Randomized, } \\
\text { double-blind, } \\
\text { placebo-con- } \\
\text { trolled trial }\end{array}$ & $\begin{array}{l}\text { Independently living older vol- } \\
\text { unteers with interest in partici- } \\
\text { pating in studies of } \\
\text { Wageningen University, Neth- } \\
\text { erlands (clinicaltrials.gov } \\
\text { NCT00124852) }\end{array}$ & $66 \cdot 5-73 \cdot 8$ & 55 & 302 & 6 & $\begin{array}{l}\text { CES-D, Center for Epidemiologic } \\
\text { Studies Depression Scale) } \\
\text { MADRS, Montgomery Asberg } \\
\text { Rating Scale } \\
\text { GDS-15, Geriatric Depression } \\
\text { Scale } \\
\text { HADS-A, Hospital Anxiety and } \\
\text { Depression Scale }\end{array}$ & $\begin{array}{l}\text { No effect of EPA + DHA sup- } \\
\text { plementation on mental well- } \\
\text { being in the general older } \\
\text { population studied. }\end{array}$ \\
\hline $\begin{array}{l}\text { Van de Rest et al. } \\
(2009)^{(51)}\end{array}$ & $\begin{array}{l}\text { Randomized, } \\
\text { double-blind, } \\
\text { placebo-con- } \\
\text { trolled trial }\end{array}$ & $\begin{array}{l}\text { Independently living older vol- } \\
\text { unteers }\end{array}$ & $66 \cdot 5-73 \cdot 8$ & 55 & 302 & 6 & $\begin{array}{l}\text { WHOQOL-BREF, short version of } \\
\text { the World Health Organization } \\
\text { quality of life questionnaire }\end{array}$ & $\begin{array}{l}\text { Supplementation with high or } \\
\text { low doses of fish oil contain- } \\
\text { ing EPA + DHA did not influ- } \\
\text { ence the quality of life of } \\
\text { healthy older individuals }\end{array}$ \\
\hline $\begin{array}{l}\text { Folsom \& Demissie } \\
(2004)^{(52)}\end{array}$ & $\begin{array}{l}\text { Prospective } \\
\text { cohort }\end{array}$ & $\begin{array}{l}\text { Old women initially free of } \\
\text { heart disease and cancer } \\
\text { (from lowa Women's Health } \\
\text { Study }\end{array}$ & $55-69$ & 0 & 720 & 168 & $\begin{array}{l}\text { Total mortality } \\
\text { Cause-specific mortality: cardio- } \\
\text { vascular; coronary heart disease; } \\
\text { stroke; cancer }\end{array}$ & $\begin{array}{l}\text { There was an inverse associ- } \\
\text { ation between total mortality } \\
\text { and fish intake. } \\
\text { Estimated marine omega-3 } \\
\text { fatty acid intake was not } \\
\text { associated with total mortality } \\
\text { or cause-specific deaths. } \\
\text { Total mortality also was not } \\
\text { associated separately with } \\
\text { eicosapentaenoic or docosa- } \\
\text { hexaenoic acids. }\end{array}$ \\
\hline $\begin{array}{l}\text { Einvik et al. } \\
(2010)^{(53)}\end{array}$ & Intervention & $\begin{array}{l}\text { A group of elderly men, from } \\
\text { The Diet and Omega-3 Inter- } \\
\text { vention Trial (DOIT), predomi- } \\
\text { nantly without earlier clinical } \\
\text { manifestations of cardiovas- } \\
\text { cular disease. }\end{array}$ & $64-76$ & 100 & 563 & 36 & $\begin{array}{l}\text { All-cause mortality } \\
\text { Cause-specific mortality: cardio- } \\
\text { vascular/noncardiovascular. } \\
\text { Cardiovascular events: fatal/non- } \\
\text { fatal }\end{array}$ & $\begin{array}{l}\text { A tendency toward reduction } \\
\text { in all-cause mortality in the } n \text { - } \\
3 \text { polyunsaturated fatty acids } \\
\text { groups. No effects was } \\
\text { observed on cardiovascular } \\
\text { events. }\end{array}$ \\
\hline
\end{tabular}


benefits, albeit by different mechanisms. Actually, prospective studies have shown that the Mediterranean diet is associated with slower cognitive decline and a reduced risk of progression $^{(55)}$. Oleic acid, the major component of olive oil, has recently shown to provide a satiety factor, oleylethanolamide, which enhances memory consolidation without crossing the blood-brain barrier ${ }^{(56)}$. This is important in verbal learning, organization, and memory. Oleoythanolamide is a mediator in maintaining cognitive function that it is not related to vascular or other nonvascular biological mechanisms (ie, metabolic, oxidative, and inflammatory). Thus, this evidence suggest that these RCTs should consider the benefits of oleic acid as well as omega-3 PUFA in protecting against age-associated cognitive decline and maintaining cognitve function in later life.

More prospective studies, as well as intervention studies investigating the association between $n-3$ PUFA and domainspecific measures are needed to clarify the current conflicting results observed in the literature, although these results are promising and encourage promotion higher intakes of $n$-3 PUFA in the diet or specifics supplements since it seems to have substantial benefits in reducing their risk of cognitive decline ${ }^{(13)}$. Earlier intervention is a key factor in potentially treating age-related memory disorders and the maintenance of healthy brain during aging.

The elderly are particularly susceptible to infections due to a decline in immune function with age ${ }^{(31)}$. The infections also tend to have more severe consequences. Aging results in declines in lymphocyte functioning and proliferation, reductions in antibody formation, and declines on hormones necessary for thymus gland functioning. Environmental factors leading to declines in immune function include certain drug use, and deficiencies in nutrients required for immune function $^{(14)}$. These deficiencies can be due to a reduction in food intake, as well as a reduced absorption and metabolism of nutrients. Active infections can increase the requirements for certain nutrients, and concomitant diseases can increase the morbidity of infections. Normal aging is accompanied by diverse changes in the immune system. Altered function of both T- and B-cells can be shown by losses in proliferative ability and interleukin- 2 and interferon synthesis. This discusses the changes in immune function in the elderly that may be mediated by the intake/status of $n-3$ fatty acids, and the potential clinical implications of these changes in their metabolism. Only five studies related to this issue were included. The most stimulating global observation is that even low doses of omega- 3 fatty acids may be sufficient to affect the immune response in elderly people under moderate dietary supplementation ${ }^{(43-45)}$. However, an important pitfall of all these studies is that those have not been evaluation long-term effects but also the impact on immunological biomarkers after supplementation is ceased.

A total of three studies were identified that described the effects of omega-3 fatty acids on bone health or muscles tonus with normal aging. Although clear scientific evidence seems to be still insufficient, the three of them described positive outcomes from dietary and supplemental omega-3 fatty acids. The most relevant observation in relation to bone health is the very recent cohort study by Farina et $a l .{ }^{(47)}$ in which a long-term (four years changes) effect of consuming fatty fish has been assessed: maintenance of femoral neck bone mineral density either in men or women were well kept. Unfortunately, this is the only powerful study that we considered able to be included in the systematic review. As for the muscle tonus, supplementation with omega-3 fatty acids seems to be very useful and promising to stimulate the complicated protein synthesis during healthy aging ${ }^{(57)}$. In fact, these nutrients may be considered of critical importance to prevent sarcopenia. Finally, undoubtedly clinical trials are urgent to test the effectiveness of these interventions with omega 3 in reducing the loss of bone health and muscle mass and function associated to normal aging ${ }^{(47)}$.

Public health efforts to promote health and functional independence are critical strategies in helping older adults stay healthy ${ }^{(58)}$. Research has shown that poor health does not have to be an inevitable consequence of aging ${ }^{(1,59)}$. Older adults who practice healthy behaviors, take advantage of clinical preventive services, and continue to engage with family and friends are more likely to remain healthy, live independently, and incur fewer health-related $\operatorname{costs}^{(2)}$. An essential component to keeping older adults healthy is preventing chronic diseases and reducing associated complications. About $80 \%$ of older adults have one chronic condition, and $50 \%$ have at least two. Infectious diseases (such as influenza and pneumococcal disease) and injuries also take a disproportionate toll on older adults.

In the present systematic review, only two RCT studies reached the criteria for inclusion and discussion. The outcomes to be evaluated after supplementation with EPA and DHA were mental well-being, physical health, psychological health and social relationship with no differences observed reagardless of high vs. moderate dose $\mathrm{e}^{(39,41-42,50,51)}$

As for mortality an inverse age-and energy-adjusted association between total mortality and fish intake was found. In general, a tendency toward reduction in all-cause mortality is observed after EPA and DHA supplementation although the positive effect seems to be within a better dietary and quality of life patterns ${ }^{(53)}$.

\section{Acknowledgements}

There are no conflicts of interest for the authors.

Natalia Úbeda (NU) was mainly involved in the design of the search strategies, the inclusion criteria, abstracted the data and quality assessment and the preparation of the methods, results and discussion sections of the manuscript. Finally, NU reviewed carefully the whole manuscript.

María Achón (MA) was mainly involved in the design of the search strategies, the inclusion criteria, abstracted the data and checked the accuracy once NU abstracted the data. MA was also involved in the preparation of the methods, results and discussion sections of the manuscript. Finally, MA reviewed carefully the whole manuscript.

Gregorio Varela-Moreiras (GVM) had the overall the responsibility of the systematic review. He was mainly involved in the design of the search strategies, and was also involved in the 
introduction and discussion sections of the manuscript but also the final preparation of the systematic review.

No funding was provided for the present work.

\section{References}

1. American Dietetic Association (2005) Position paper of the American Dietetic Association: Nutrition Across the Spectrum of Aging. J Am Diet Assoc 105, 616-633.

2. Blacklow RS (2007) Actuarially speaking: an overview of life expectancy. What can we anticipate? Am J Clin Nutr 86, 1560S-1562S.

3. Futureage, A road map for ageing research (2010) The University of Sheffield, Sociological Studies (report)

4. Goulding MR, Rogers ME \& Smith SM (2003) Public Health and aging. Trends in aging-United States and worldwide. MMWR 52, 101-106.

5. Knoops KTB, de Groot L, Kromhout D, et al. (2004) Mediterranean Diet, Lifestyle Factors, and 10-Year Mortality in Elderly European Men and Women, The HALE Project. JAMA 292, 1433-1439.

6. Kozlowska K, Szczecinska A, Roszkowski W, et al. (2008) Patterns of healthy lifestyle and positive health attitudes in older europeans. J Nutr Health Aging 12, 728-734.

7. Schroll K, Carbajal A, Decarli B, Martins I, Grunenberger F, Blauw YH \& de Groot CP (1996) Food patterns of elderly Europeans. SENECA Investigators. Eur J Clin Nutr 50, Suppl. 2, S86-100.

8. Vincent D, Lauque S, Lanzmann D, et al. (1998) Changes in dietary intakes with age. J Nutr Health Aging 2, 45-48.

9. Wakimoto P \& Block G (2001) Dietary intake, dietary patterns, and changes with age: An epidemiological perspective. J Gerontol A Biol Sci Med Sci. 56A, 65-80.

10. Blanc S, Schoeller DA, Bauer D, et al. (2004) Energy requirements in the eight decade of life. Am J Clin Nutr 79, 303-310.

11. Foote JA, Giuliano AR \& Harris RB (2000) Older adults need guidance to meet nutritional recommendations. J Am Coll Nutr 19, 628-640.

12. Dean M, Raats MM, Grunert KG \& Lumbers M (2009) Factors influencing eating a varied diet in old age. Public Health Nutr 12, 2421-2427.

13. Buhr G \& Bales CW (2009) Nutritional supplements for older adults: review and recommendations-Part I. Journal of Nutrition for the Elderly 28, 5-29.

14. Everitt AV, Hilmer SN, Brand-Miller JC, Jamieson HA, Truswell AS, Sharma AP, Mason RS, Morris BJ \& Le Couteur DG (2006) Dietary approaches that delay age-related diseases. Clin Interv Aging 1, 11-31.

15. Lichtenstein A, Rasmussen H, Yu W, et al. (2008) Modified My Pyramid for Older Adults. J Nutr 138, 5-11.

16. Riediger ND, Othman RA, Miyoung S, et al. (2009) A systemic review of the roles of $n-3$ fatty acids in health and disease. J Am Diet Assoc 109, 668-679.

17. Kamphuis MH, Geerlings MI, Tijhuis MAR, et al. (2006) Depression and cardiovascular mortality: a role for $n-3$ fatty acids? Am J Clin Nutr 84, 1513-1517.

18. Whelan J (2008) (n-6) and (n-3) Polyunsaturated fatty acids and the aging brain: food for thought. J Nutr 138, $2521-2522$

19. Bazan NG (2006) Cell survival matters: docosahexanoic acid signaling, neuroprotection and photoreceptors. Trends Neurosci 29, 263-271.

20. Beydoun MA, Kaufman JS, Satia JA, et al. (2007) Plasma $n-3$ fatty acids and the risk of cognitive decline in older adults: the Atherosclerosis Risk in Communities Study. Am J Clin Nutr 85, 4, 1103-1111.

21. Bourre JM \& Paquotte P (2008) Seafood (wild and farmed) for the elderly: contribution to the dietary intakes of iodine, selenium, DHA and vitamins B12 and D. I Nutr Health Aging 12, 186-192.

22. Cole GM \& Frautschy SA (2010) DHA may prevent agerelated dementia. J Nutr 140, 869-874.

23. Dangour A \& Uauy R (2008) N-3 long-chain polyunsaturated fatty acids for optimal function during brain development and ageing. Asia Pac J Clin Nutr 17, S1, 185-188.

24. Dangour AD, Allen E, Elbourne D, et al. (2010) Effect of 2-y $n$-3 long-chain polyunsaturated fatty acid supplementation on cognitive function in older people: a randomized, double-blind, controlled trial. Am J Clin Nutr 91, 6, $1725-1732$

25. Huang TL (2010) Omega-3 fatty acids, cognitive decline, and Alzheimer's disease: a critical review and evaluation of the literature. Journal of Alzheimer's Disease 21, 673-690.

26. Issa AM, Mojica WA, Morton SC, et al. (2006) The efficacy of omega-3 fatty acids on cognitive function in aging and dementia: a systematic review. Dement Geriatr Cogn Disord 21, 88-96.

27. Lukiw WJ \& Bazan NG (2008) Docosahexanoic acid and the aging brain. J Nutr 138, 2510-2514

28. Caprari P, Scuteri A, Salvati AM, et al. (1999) Aging and red blood cell membrane: a study of centenarians. Exp Gerontol 34, 47-57.

29. Sands SA, Reid KJ, Windsor SL \& Harris WS (2005) The impact of age, body mass index, and fish intake on the EPA and DHA content of human erythrocytes. Lipids $\mathbf{4 0}$ 343-347

30. Itomura M, Fujioka S, Hamazaki K, et al. (2008) Factors influencing EPA + DHA levels in red blood cells in Japan. In vivo 22, 131-135.

31. Rees D, Miles EA, Banerjee T, et al. (2006) Dose-related effects of eicosapentaenoic acid on innate immune function in healthy humans: a comparison of young and older men. Am J Clin Nutr 83, 2, 331-342.

32. Plourde M, Tremblay-Mercier J, Fortier M, Pifferi F \& Cunnane SC (2009) Eicosapentaenoic acid decreases postprandial beta-hydroxybutyrate and free fatty acid responses in healthy young and elderly. Nutrition $\mathbf{2 5}$, 289-294

33. Vandal M, Freemantle E, Tremblay-Mercier J, et al. (2008) Plasma omega-3 fatty acid response to a fish oil supplement in the healthy elderly. Lipids 43, 1085-1089.

34. Garry PJ, Hunt WC, Koehler KM, VanderJagt DJ \& Vellas BJ (1992) Longitudinal study of dietary intakes and plasma lipids in healthy elderly men and women. Am J Clin Nutr 55, 682-688.

35. Uauy R \& Valenzuela A (2000) Marine oils: the health benefits of $n$-3 fatty acids. Nutrition 16, 680-684.

36. Avenell A \& Handoll HH (2005) Nutritional supplementation for hip fracture aftercare in older people. Cochrane Database Syst Rev Apr 18, 2, CD001880.

37. Vercambre MN, Boutron-Ruault MC, Ritchie K, et al. (2009) Long-term association of food and nutrient intakes with cognitive and functional decline: a 13-year follow-up study of elderly French women. Br J Nutr 102, 3, 419-427.

38. Dullemeijer C, Durga J, Brouwer IA, et al. (2007) n-3 fatty acid proportions in plasma and cognitive performance in older adults. Am J Clin Nutr 86, 5, 1479-1485.

39. Van de Rest O, Geleijnse JM, Kok FJ, et al. (2008a) Effect of fish oil on cognitive performance in older subjects: a randomized, controlled trial. Neurology 71, 6, 430-438. 
40. Ortega RM, Requejo AM, Andrés P, et al. (1997) Dietary intake and cognitive function in a group of elderly people. Am J Clin Nutr 66, 4, 803-809.

41. Laurin D, Verreault R, Lindsay J, et al. (2003) Omega-3 fatty acids and risk of cognitive impairment and dementia. $J$ Alzheimers Dis 5, 4, 315-322.

42. Van de Rest O, Spiro A 3rd, Krall-Kaye E, et al. (2009b) Intakes of ( $n-3)$ fatty acids and fatty fish are not associated with cognitive performance and 6-year cognitive change in men participating in the Veterans Affairs Normative Aging Study. J Nutr 139, 12, 2329-2336.

43. Thies F, Nebe-von-Caron G, Powell JR, et al. (2001a) Dietary supplementation with gamma-linolenic acid or fish oil decreases $\mathrm{T}$ lymphocyte proliferation in healthy older humans. J Nutr 131, 7, 1918-1927.

44. Bechoua S, Dubois M, Véricel E, et al. (2003) Influence of very low dietary intake of marine oil on some functional aspects of immune cells in healthy elderly people. $\mathrm{Br} J$ Nutr 89, 4, 523-531.

45. Wardwell L, Chapman-Novakofski K, Herrel S, et al. (2008) Nutrient intake and immune function of elderly subjects. $J$ Am Diet Assoc 108, 12, 2005-2012.

46. Thies F, Nebe-von-Caron G, Powell JR, et al. (2001b) Dietary supplementation with eicosapentaenoic acid, but not with other long-chain $n-3$ or $n-6$ polyunsaturated fatty acids, decreases natural killer cell activity in healthy subjects aged $>55$ y. Am J Clin Nutr 73, 3, 539-548.

47. Farina EK, Kiel DP, Roubenoff R, et al. (2011) Protective effects of fish intake and interactive effects of long-chain polyunsaturated fatty acid intakes on hip bone mineral density in older adults: the Framingham Osteoporosis Study. Am J Clin Nutr, doi: 10.3945/ajcn110.005926.

48. Robinson SM, Jameson KA, Batelaan SF, Hertfordshire Cohort Study Group, et al. (2008) Diet and its relationship with grip strength in community-dwelling older men and women: the Hertfordshire cohort study. J Am Geriatr Soc 56, 1, 84-90.

49. Smith GI, Atherton P, Reeds DN, et al. (2011) Dietary omega3 fatty acid supplementation increases the rate of muscle protein synthesis in older adults: a randomized controlled trial. Am J Clin Nutr 93, 2, 402-412.

50. Van de Rest O, Geleijnse JM, Kok FJ, et al. (2008b) Effect of fish-oil supplementation on mental well-being in older subjects: a randomized, double-blind, placebo-controlled trial. Am J Clin Nutr 88, 3, 706-713.

51. Van de Rest O, Geleijnse JM, Kok FJ, et al. (2009a) Effect of fish oil supplementation on quality of life in a general population of older Dutch subjects: a randomized, doubleblind, placebo-controlled trial. J Am Geriatr Soc 57, 8, 1481-1486.

52. Folsom AR \& Demissie Z (2004) Fish intake, marine omega-3 fatty acids, and mortality in a cohort of postmenopausal women. Am J Epidemiol 160, 10, 1005-1010.

53. Einvik G, Klemsdal TO, Sandvik L, et al. (2010) A randomized clinical trial on $n-3$ polyunsaturated fatty acids supplementation and all-cause mortality in elderly men at high cardiovascular risk. Eur J Cardiovasc Prev Rehabil 17, 5 , 588-592.

54. Rosales FJ (2011) No differential effect between docosahexaenoic acid and oleic acid in preventing cognitive decline. Am J Clin Nutr 93, 2, 476-477.

55. Panza F, Frisardi V, Seripa D, et al. (2010) Dietary unsaturated fatty acids and risk of mild cognitive impairment. J Alzheimers Dis 21, 867-870.

56. Campolongo P, Roozedndaal B, Trezza V, et al. (2009) Fat-induced satiety factor oleoylethanolamide enhances memory consolidation. Proc Natl Acad Sci USA 106, 8027-8031.

57. Amarantos E, Martinez A \& Dwyer J (2001) Nutrition and quality of life in older adults. J Gerontol Biol Sci Med Sci. 56A, 54-64.

58. Armstrong R, Doyle J, Lamb C, et al. (2006) Multi-sectoral health promotion and public health: the role of evidence. J Public Health (Oxf) 28, 168-172.

59. Gillette S, Abellan G \& Andrieu S (2007) IANA task force on nutrition and cognitive decline with aging. J Nutr Health Aging 11, 132-152.

60. Kalmijn S, Feskens EJ, Launer LJ, et al. (1997) Polyunsaturated fatty acids, antioxidants, and cognitive function in very old men. Am J Epidemiol 145, 1, 33-41.

61. Vakhapova V, Cohen T, Richter Y, et al. (2010) Phosphatidylserine containing omega- 3 fatty acids may improve memory abilities in non-demented elderly with memory complaints: a double-blind placebo-controlled trial. Dement Geriatr Cogn Disord 29, 5, 467-474.

62. Johnson EJ, McDonald K, Caldarella SM, et al. (2008) Cognitive findings of an exploratory trial of docosahexaenoic acid and lutein supplementation in older women. Nutr Neurosci. 2, 75-83.

63. Whalley LJ, Fox HC, Wahle KW, et al. (2004) Cognitive aging, childhood intelligence, and the use of food supplements: possible involvement of $n-3$ fatty acids. Am J Clin Nutr 80, 6, 1650-1657.

64. Heude B, Ducimetière P \& Berr C (2003) Cognitive decline and fatty acid composition of erythrocyte membranes-The EVA Study. Am J Clin Nutr 77, 4, 803-808.

65. Velho S, Marques-Vidal P, Baptista F, et al. (2007) Dietary intake adequacy and cognitive function in free-living active elderly: a cross-sectional and short-term prospective study. Clin Nutr 27, 1, 77-86.

66. Yurko-Mauro K (2010a) Cognitive and cardiovascular benefits of docosahexanoic acid in aging and cognitive decline. Current Alzheimer Research 7, 190-196.

67. González S, Huerta JM, Fernández S, et al. (2010) The relationship between dietary lipids and cognitive performance in an elderly population. Int J Food Sci Nutr 61, 2, 217-225.

68. Richter Y, Herzog Y, Cohen T, et al. (2010) The effect of phosphatidylserine-containing omega-3 fatty acids on memory abilities in subjects with subjective memory complaints: a pilot study. Clin Interv Aging 5, 313-316.

69. Lauretani F, Bandinelli S, Bartali B, et al. (2007) Omega-6 and omega-3 fatty acids predict accelerated decline of peripheral nerve function in older persons. Eur J Neurol 14, 7, 801-808.

70. Roberts RO, Cerhan JR, Geda YE, et al. (2010) Polyunsaturated fatty acids and reduced odds of MCI: the Mayo Clinic Study of Aging. J Alzheimers Dis 21, 3, 853-865.

71. Matsumoto I, Yamashita K \& Matsuoka A (2009) Docosahexaenoic asid and cognition in elderly people living in community - A 4-year follow-up study. Alzheimer's E Dementia: The Journal of the Alzheimer's Association $5 S \mathbf{4}$, 282.

72. Requejo AM, Ortega RM, Robles F, et al. (2003) Influence of nutrition on cognitive function in a group of elderly, independently living people. Eur J Clin Nutr 57, Suppl 1, S54-S57.

73. Kesse-Guyot E, Péneau S, Ferry M, et al. (2011) Thirteen-year prospective study between fish consumption, long-chain $n$-3 fatty acids intakes and cognitive function. $J$ Nutr Health Aging 15, 2, 115-120. 
74. Conquer JA, Tierney MC, Zecevic J, et al. (2000) Fatty acid analysis of blood plasma of patients with Alzheimer's disease, other types of dementia, and cognitive impairment. Lipids 35, 12, 1305-1312.

75. Kalmijn S, van Boxtel MP \& Ocké M (2004) Dietary intake of fatty acids and fish in relation to cognitive performance at middle age. Neurology 62, 2, 275-280.
76. Morris MC, Evans DA, Tangney CC, et al. (2005) Fish consumption and cognitive decline with age in a large community study. Arch Neurol 62, 12, 1849-1853.

77. Van Gelder BM, Tijhuis M, Kalmijn S, et al. (2007) Fish consumption, $n-3$ fatty acids, and subsequent 5-y cognitive decline in elderly men: the Zutphen Elderly Study. Am J Clin Nutr 85, 4, 1142-1147. 